\title{
Culture and tourism: perspectives of foreigners on the Brazilian carnival
}

\author{
A. F. Porto \\ Department of Tourism, Federal University of Ouro Preto, Brazil
}

\begin{abstract}
The objective of this work is to try and gain a better understanding about the motives that lead a tourist to visit Brazil, and also to gauge the final perception of the tourist about their visit. The question "why do people travel to Brazil" is complex, involving cultural and psychological aspects (such as the attraction for the Latin culture or for the tropical heat), transport, availability of tourist facilities, distance, motivation and economic considerations. All of this we call the "tourist experience". There is also the fact to be considered that the revisit rate, by tourists to Brazil, is high. In 2006, 64\% of the tourists interviewed by Embratur had already visited the country at least once. This shows a high fidelity for the quality of the Brazilian reception. What is the reason for this fidelity, how does it happen, and what is the final image the foreign tourist has about Brazil; these are the foci of the research in question. One of the major reasons for the image of Brazil in the outside world, as well as being the period with the most visits by foreign tourists, the Carnival is by definition a focus of the research.
\end{abstract}

Keywords: tourism, carnival, image, Brazil, Ouro Preto, Recife, Olinda, Rio de Janeiro, perspectives, foreigners.

\section{Introduction}

The objective of this work is gain a better understanding of the motivations that leads a tourist to visit Brazil, and also what is the final perception of tourists when their visit is over. The question "why people travel to Brazil" is quite complex, involving cultural aspects, transport, the availability of tourist facilities, distance, motivation and economic factors. All this, we call the "travel experience of tourists" [1]. There is also another relevant factor to consider: the 
rate of return of tourists to Brazil is high. In 2006, $64 \%$ of tourists interviewed by Embratur had already visited the country at least once. This indicates a high capacity for loyalty to the Brazilian way of receiving visitors. The reason for such loyalty, and the final image that foreign tourists have of Brazil, are the focus of the text in question.

As the major event responsible for Brazil's image abroad, as well being the peak period for visits by foreign tourists, we use the Carnival as a focus of our research. We suggest the following hypotheses: 1) The Carnival is a positive inducer of Brazilian tourism. It is presented as being exclusive to Brazil, contributing by virtue of this image, to the recognition of Brazil as a major tourist destination in the world today. 2) However, despite this recognition, the diversity of the Brazilian Carnival is still unknown. In most cases only the Carioca Carnival is recognized by the foreign tourist visiting the country for the first time, leaving the Carnivals of the northeast and the interior of the country for a second trip.

The interviews took place with foreign tourists in the cities of Ouro Preto, Olinda/Recife and Rio de Janeiro, during periods of Carnival. Thus, we designed and analyzed, using the technique of phenomenological analysis units, the image of Brazil and its Carnival, one of the largest spontaneous street celebrations in the world, from the perspective of foreign tourists visiting Brazil in this period.

\section{Brazil and tourism}

Choosing a tourist destination for any individual is not an easy task. When we decide to travel, cultural and psychological aspects, such as attraction to the culture of a country, or a certain climate, as well as transportation problems, the availability of tourist facilities, distance and economic considerations are taken into account. With respect to work and the pursuit of leisure and pleasure in its broadest sense, it has become common discussion in the postmodern world of how to reconcile the practice of pleasure with dedication to work [2]. In our leisure time, we seek not only to behave as one of the masses that invade tourist destinations in high season. Increasingly, the segmentation of destinations, niche and unexplored markets, globalized customer reception practices, show that the huge conglomerated experience, conceived and built just for the reception, accommodation and entertainment of tourists, does not account for the behavior of current tourist demand [3].

But what about today's tourists visiting Brazil? What is the profile of foreign visitor? Brazil receives about 6.5 (six and a half) million foreign tourists per year. Of these, 28,09\% are from Latin America, (14,38\%) United States, and Europe $(30.67 \%)$. The largest oriental country with $1.5 \%$ or 75,000 tourists is Japan (Table 1).

Despite these impressive numbers, Brazil is very small compared to world tourism. Every year the figure is 846 million international arrivals. As we can see, (Table 2), Brazil had a total of 6,534,244 tourists for the period of 2007, with 5,600,000 arriving in 2009, with the drop mainly due to the American and 
Table 1: Principal country sources of tourists to Brazil. Source: FPD and Embratur.

\begin{tabular}{|c|c|c|c|c|c|c|}
\hline $\begin{array}{c}\text { Principal country } \\
\text { sources }\end{array}$ & 2006 & & & 2007 & & \\
\hline & Tourists & $\%$ & Ranking & Tourists & $\%$ & Ranking \\
\hline ARGENTINA & 933.061 & 18,60 & $1^{\circ}$ & 920.210 & 18,31 & $1^{\circ}$ \\
\hline U.S.A. & 721.633 & 14,38 & $2^{\circ}$ & 699.169 & 13,91 & $2^{\circ}$ \\
\hline PORTUGAL & 299.211 & 5,96 & $3^{\circ}$ & 280.438 & 5,58 & $3^{\circ}$ \\
\hline ITÁLY & 287.898 & 5,74 & $4^{\circ}$ & 268.685 & 5,35 & $4^{\circ}$ \\
\hline CHILE & 176.357 & 3,52 & $10^{\circ}$ & 260.430 & 5,18 & $5^{\mathbf{o}}$ \\
\hline GERMANY & 277.182 & 5,52 & $5^{\circ}$ & 257.719 & 5,13 & $6^{\circ}$ \\
\hline FRANCE & 275.913 & 5,50 & $6^{\circ}$ & 254.367 & 5,06 & $7^{\circ}$ \\
\hline URUGUAI & 255.349 & 5,09 & $7^{\circ}$ & 226.111 & 4,50 & $8^{\circ}$ \\
\hline SPAIN & 211.741 & 4,22 & $8^{\circ}$ & 216.373 & 4,31 & $9^{\circ}$ \\
\hline PARAGUAI & 198.958 & 3,97 & $9^{\circ}$ & 206.323 & 4,11 & $10^{\circ}$ \\
\hline ENGLAND & 169.627 & 3,38 & $11^{\circ}$ & 176.948 & 3,52 & $11^{\circ}$ \\
\hline PERU & 64.002 & 1,28 & $15^{\circ}$ & 96.336 & 1,92 & $12^{\circ}$ \\
\hline HOLAND & 86.122 & 1,72 & $12^{\circ}$ & 83.554 & 1,66 & $13^{\circ}$ \\
\hline SWITZERLAND & 84.816 & 1,69 & $13^{\circ}$ & 72.763 & 1,45 & $14^{\circ}$ \\
\hline CANADÁ & 62.603 & 1,25 & $16^{\circ}$ & 63.963 & 1,27 & $15^{\circ}$ \\
\hline JAPAN & 74.638 & 1,49 & $14^{\circ}$ & 63.381 & 1,26 & $16^{\circ}$ \\
\hline OTHERS & 838.140 & 16,71 & - & 879.064 & 17,49 & - \\
\hline Total & 5.017 .251 & & & 5.025 .834 & & \\
\hline
\end{tabular}

Table 2: Landing passengers on international flights - monthly variation 2007/08. Source: Infraero.

\begin{tabular}{|c|c|c|c|c|c|c|}
\hline $\begin{array}{l}\text { Principais Países } \\
\text { Emissores }\end{array}$ & 2006 & & & 2007 & & \\
\hline & Tourists & $\%$ & Ranking & Tourists & $\%$ & Ranking \\
\hline ARGENTINA & 933.061 & 18,60 & $1^{\circ}$ & 920.210 & 18,31 & $1^{\circ}$ \\
\hline U.S.A. & 721.633 & 14,38 & $2^{\circ}$ & 699.169 & 13,91 & $2^{\circ}$ \\
\hline PORTUGAL & 299.211 & 5,96 & $3^{\circ}$ & 280.438 & 5,58 & $3^{\circ}$ \\
\hline ITÁLY & 287.898 & 5,74 & $4^{\circ}$ & 268.685 & 5,35 & $4^{\circ}$ \\
\hline CHILE & 176.357 & 3,52 & $10^{\circ}$ & 260.430 & 5,18 & $5^{\circ}$ \\
\hline GERMANY & 277.182 & 5,52 & $5^{\circ}$ & 257.719 & 5,13 & $6^{\circ}$ \\
\hline FRANCE & 275.913 & 5,50 & $6^{\circ}$ & 254.367 & 5,06 & $7^{\circ}$ \\
\hline URUGUAY & 255.349 & 5,09 & $7^{\circ}$ & 226.111 & 4,50 & $8^{\circ}$ \\
\hline SPAIN & 211.741 & 4,22 & $8^{\circ}$ & 216.373 & 4,31 & $9^{\circ}$ \\
\hline PARAGUAY & 198.958 & 3,97 & $9^{\circ}$ & 206.323 & 4,11 & $10^{\circ}$ \\
\hline ENGLAND & 169.627 & 3,38 & $11^{\circ}$ & 176.948 & 3,52 & $11^{\circ}$ \\
\hline PERU & 64.002 & 1,28 & $15^{\circ}$ & 96.336 & 1,92 & $12^{\circ}$ \\
\hline HOLLAND & 86.122 & 1,72 & $12^{\circ}$ & 83.554 & 1,66 & $13^{\circ}$ \\
\hline SWITZERLAND & 84.816 & 1,69 & $13^{\circ}$ & 72.763 & 1,45 & $14^{\circ}$ \\
\hline CANADA & 62.603 & 1,25 & $16^{\circ}$ & 63.963 & 1,27 & $15^{\circ}$ \\
\hline JAPAN & 74.638 & 1,49 & $14^{\circ}$ & 63.381 & 1,26 & $16^{\circ}$ \\
\hline OTHERS & 838.140 & 16,71 & - & 879.064 & 17,49 & - \\
\hline Total & 5.017 .251 & & & 5.025 .834 & & \\
\hline
\end{tabular}


world crisis of 2008. Brazil represents about $0.7 \%$ of the total movement of tourists travelling worldwide, it is in the $43^{\text {rd }}$ position in terms of world tourism.

There is a broad field of action in world tourism, where Brazil has not played a role of "player" or "player" internationally, called the mass Hospitality and Tourism Industry. Soon, although not yet, Brazil's image in the world as an excellent tourist destination will be consolidated and recognized throughout the world.

\section{Perspectives of foreigners and the Carnival of Brazil}

When studying the image of Brazil, even through the iconography of the media associated with the country or through the statements of individuals, we note that the Carnival, in one form or another, is always present in the mind of the foreigner.

Doing a search for images related to Brazil, using Google Images, we can illustrate this view. Google Images is one of the most used internet tools utilized by tourists today in search of primary information about their desired destination. What formerly took place through travel agencies, today is through internet search. Google allows the selection of typical features or images of a destination. Discounting flags, symbols, pictures of people and tourists, we find images that are characteristic of the perception that foreigners have of a particular destination. That is, we can delineate the imaginary images by selecting this destination. In Brazil's case, selecting the images (Figure 1) we find the following fact:

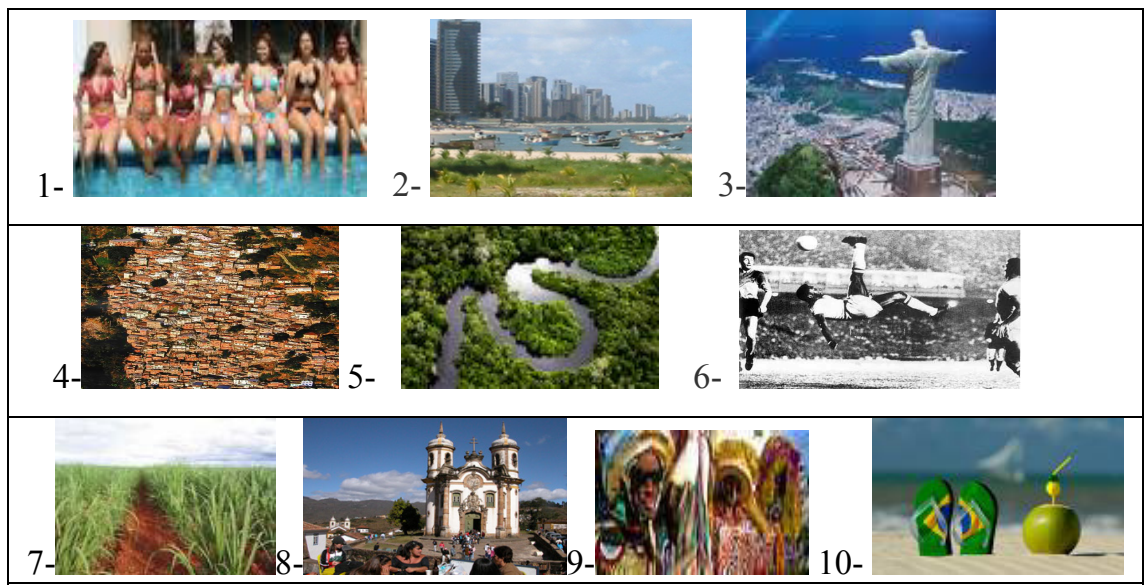

Figure 1: Illustrations of Brazil's image abroad 1-Brazilian women (photo: A. Porto), 2-beaches (A. Porto), 3-Rio de Janeiro (Embratur), 4Favela and violence (A. Porto); 5-Amazon (J. Pereira), 6-football and Pele (CBF), 7-sugarcane (Embrapa), 8-Baroque Church (A. Porto), 9-Caboclo maracatu (Embratur), 10-Haviano sandals (Alex Uchoa). 
Icons aside, the Brazilian brand is very closely related to sports and carnival. The carnival has become the main reason for travel to the country, behind only beaches, which means that the carnival has become the largest promoter of tourism in Brazil, as illustrated where the carnival also has beaches, such as the cities of Rio de Janeiro, Salvador and Recife.

Cultural tourism is therefore linked to popular festivals that are linked to this pagan festival. Rio de Janeiro is the most popular Brazilian destination and the New Year's Eve Festival and Carnival are its major cultural events. Thus, the choice of the research in question was to check the views of foreigners about Brazil during Carnival.

Another dimension that we want to give the research, apart from the perspectives of foreigners, Brazilian international relations and Brazil's image abroad, is to draw a profile of the image of Brazil and the Brazilian Carnival from the testimony of visiting tourists from the cities of Ouro Preto, Recife and Rio de Janeiro.

The visits researched were: Ouro Preto - Carnival (Feb. 2006) and Winter Festival (July 2007/09); Olinda/Recife - Carnival (February 2007), Rio de Janeiro - Carnival (Feb. 2008) and the Pan American Games (July 2007).

The interviews were focused on foreigners who were passing the carnival in the cities surveyed. We attempted to follow a logic in the choice of them, depending on the characteristics of phenomenological research, which balances the tension between singularity and universality.

\section{Ouro Preto, the Carnival and foreign tourists}

The city of Ouro Preto is located in Minas Gerais, central Brazil. It has an average annual temperature between 6 and $28{ }^{\circ} \mathrm{C}$. In June and July, the dry winter season, temperatures can fall as low as $2{ }^{\circ} \mathrm{C}$. Located in a mountainous region, it has an average altitude of $1.116 \mathrm{~m}$, the highest point being the famous Peak Itacolomy with $1.722 \mathrm{~m}$, a natural symbol of the city. Its topography consists of only $5 \%$ of flat terrain, against $40 \%$ to $55 \%$ rolling terrain of the mountains. Most of the land is difficult to traverse and ever since the days of gold, 1700-1800 until the present day, there has been a major restriction on vehicle traffic. Ouro Preto is listed by World Heritage UNESCO, as an important world example of a baroque town.

Villa Rica became the Imperial City of Ouro Preto in 1823 and remained as capital of the Province of Minas Gerais until 1897, the year of the inauguration of Belo Horizonte. The seventeen hundreds are gone, but they bequeathed a future that today is embodied in the houses, in the colonial churches, as well as the people of Aleijadinho and Tiradentes. Students at the School of Minas, engineers by nature, have been taking care of the city center houses since the early twentieth century, creating what today is known as the "Student Republics." Today there are about 300 (three hundred) Republics, 70 of them open to the public, owned by the Federal Government and managed by the UFOP, and the rest private, where students get together and rent a house to dwell. There is a ritual among the republics in order to be accepted into student 
housing. This ritual must be gone through by the Bixo (as the new students are called) in order to be accepted as a member of the Republic, of which he/ she will remain a member throughout his/her life. There is an annual festival in October, the famous festival of 12, where the former residents return to the Republic and participate in festivities organized by current residents, including fund raising for those houses that need renovation. This inculcates, in Ouro Preto a sense of belonging for those students who lived in the city. Ouro Preto is a kind of second home for thousands of students who have passed through in UFOP's century of existence. All this, plus the title of World Heritage Site, means Ouro Preto has a prominent place both in history and in tourism in Brazil, especially during Carnival, as the republics receive revelers from all over Brazil and abroad.

To understand the Carnival de Ouro Preto it is important to know about the origin of Block Zé Pereira dos Retainers. José Nogueira Paredes or Ze (Joe) Pereira plus his followers (block), in 1848 opened the first day of Carnival in Rio de Janeiro. The idea caught on and behind the new block began to follow a group of revelers and musicians responsible for the opening party. In 1867, Zé Pereira was transferred to Ouro Preto, going to work at the Palace of the Governor. The Block Zé Pereira dos Retainers was born, organized by officials of the Palace. "Retainers" refers to subalterns who "suck-up", with their tails, top hats and lanterns, which became the trademark block ouropretano. Thus, the origin of Carnival in Ouro Preto is linked to the origin of Carnival in Rio de Janeiro. The tradition of Ze Pereira blocks have spread throughout Brazil. Since then the Carnival City has become the best festival of Minas Gerais, attracting thousands of tourists, mostly young men in search of the University Republics.

It is in this context the foreign tourists who come to the Carnival of Ouro Preto are taken for a visual tour to experience the interactivity and excitement of the people. Foreign visitors were given the following questionnaire with open questions:

1. Is this the first time you have come to Brazil? How did you make your choice to come here? Why did you choose Brazil?

2. What image did you have of Brazil before coming here?

3. What impression do you have of Brazil now?

4. Describe and comment on aspects of your experience as tourists in Brazil during carnival, that you deem to be most significant and remarkable.

Listed below are the Sense Units found in the statements of foreign tourists visiting Ouro Preto:

1 - Brazil Tropical

2 - Surprised with Ouro Preto Baroque

3 - Predominantly young people

4 - Size of Brazil

5 - Size of the Carnival

The image of Brazil in large sectors of international media, highlighting the beaches of Brazil, the heat and the nature, permeate the minds of respondents. The summer means for tourists Tropical Brazil. However, when a tourist comes to a city like Ouro Preto, the image gets changed. 
The baroque confronts the imagination of tourists. He has never imagined this type of construction in Brazil, because everyone imagines that Brazil has only new buildings and modernity. This demonstrates the international recognition of the city of Ouro Preto as a World Heritage Site. This shows how important for Ouro Preto and for the other surveyed, Olinda - PE, the title of World Heritage City is; it contributes to the recognition of Ouro Preto as a major tourist destination in Brazil, including also as it does the university.

The interviewees expressed surprise at Ouro Preto, especially with the vitality that the old city has, with the large number of young people who go for the carnival season there. The differences in colors and races found in Minas Gerais, and more specifically in Ouro Preto, make a large impact on the interviewees, since this was not what they expected. Furthermore, the inclusive, participatory carnival, with the public interacting with members of the blocks, differentiates the Brazilian carnival.

\section{Olinda/Recife, the Carnival and the foreign tourists}

The history of the region began in 1534 , when Portugal created hereditary captaincies, in a sense "fiefdoms" The origin of its name comes from the Tupi Parana Puca, meaning "the sea that breaks" or Parana-Bu, "hole in the sea" or "pit of sea". The Pernambuco captaincy was one of the few that prospered because of adaptability sugar cane to the soil of the region. Since the beginning, the culture of the Pernambuco was based on a mixture of three peoples: Europeans, Indians and Blacks. Initially, the Portuguese attempted to use Indian slave labor. However, after successive indigenous uprisings, it was decided to import manpower from Africa, which became in itself a large business.

In 1630, the captaincy was invaded by the Dutch West India Company, an event that today is illustrated in the architecture of the region, which has several buildings of the era. Moreover, Olinda is, as Ouro Preto, listed since 1982 as a World Heritage Site because of its baroque past, prior to Ouro Preto, becoming the first cycle of Brazilian Baroque. Not only are their churches a great attraction but also the colonial houses.

In this context, a tourist can cross over bridges that were designed and built by the Dutch, visit the many churches left by the Portuguese, taste various dishes of which were inherited from the indigenous culture, and dance to the sound of Maracatu rhythm, like the frevo originating in African heritage existing in Pernambuco.

The Carnival has always existed in Recife, from the time of Minho Portuguese colonizers. The festivals of Black Congo, fairly widespread Pernambuco since the eighteenth century, are considered the roots of Carnival Pernambucano. As in Ouro Preto, the festival of Congo and the investiture of African kings have always been part of the imagery of Pernambuco. Direct heir of the black Congos, Maracatu is the popular black strain, since the term refers to the gathering of blacks during the festivities in honor of Our Lady of the Rosary. Since 1888, with the end of slavery, these festivals have been black, linked to the land of Xango and Candomble, they would have been celebrated at other festival 
periods, like carnival time. The strength of frevo was born spontaneously from this mixture of races and rhythms of Pernambuco. Frevo means skipping effervescently, as if the ground is bubbling. The rhythm originates in the mix of Polka Polish and style of the orchestras of the time. As with a martial parade, but with extreme movement, frevo was born in the light of a new era of Pernambuco Carnival, at the beginning of the twentieth century.

Now Pernambuco Carnival is treated as the more traditional and therefore authentic. In 2009, according to the official site of the event, the carnival was attended by approximately 700 associations between blocks, trocas, afoxés, maracatus, giant puppets, parading through the streets and hillsides of the city. Carnival in Olinda lasts till Ash Wednesday, when 49 carnival blocks make the final parade.

In Carnival in Olinda it has become mandatory to wear some kind of fantasy costume, whether it be Ali-Baba, a nun, Spiderman, a highwayman, a giant dummy or other colorful fantasy. Even those locals who jump behind the Frevo making jokes, wear some kind of fantasy.

The interviews in the cities of Olinda and Recife were made during the Carnival in the old center of Recife and Varadouro in Olinda, where there exists several cultural centers. In addition, interviews were made at Boa Viagem beach, where there is a craft fair, which is also an obligatory stop for foreign tourists to buy crafts and eat Brazilian food. There you will easily find groups of Dutch, Italian, American or Jewish tourists.

The questions put to foreign tourists were the same as in Ouro Preto. The sense found and analysis were as follows:

\section{1 - Brazil Tropical}

2 - The benefits of coming to the Northeast over the Southeast

3 - Good food and drink

\section{4 - Colorful and joyful Streets}

The question of distance, combined with more affordable prices and the differentiated Carnival, make Recife emerge as a great alternative to the tourist, and an incentive to return to the country. These statements are the key differences between Rio de Janeiro and Recife. In Recife the diversity of food is a point of attraction. Being a coastal urban region, meats and fish are plentiful, with prices much lower than found elsewhere in the world. Prices that compete with Brazil in the world in this category are Thailand and India, also China. However, these countries are farther away for most of the principal tourist generating countries. Further, the preparation of food in Brazil is much closer to the west than the east.

The typical Pernambuco Carnival is an attraction in itself. The colorful festivals are noticeable, especially in small coastal towns and lately also in the inner cities and greater Recife. Olinda is one of the most colorful cities in Brazil when it comes to Carnival. The music in Recife is the big difference compared to all other carnivals in the world. Frevo and Maracatu are Pernambucana creations. There is nothing like it in the world that compares with the vitality of these two basically percussive rhythms. 


\section{Rio de Janeiro, the Carnival and foreign tourists}

Rio de Janeiro was always the giant and creative hub that radiated culture. Since the seventeenth century, there has been talk of the Carnival in Rio de Janeiro. This Portuguese custom can be divided into two types: the Family Carnival and Popular Carnival. Very common in Rio de Janeiro, Family Carnival eventually was overwhelmed by the so-called Popular Carnival, as the close proximity of the houses of families propitiated such contact.

This confrontation in Rio de Janeiro was facilitated by the phenomenon of urbanity, which started at that time, mainly in Rio de Janeiro, due to its topography and formation, with beaches on one side and hills on the other [5]. Debret portrays this fact in his watercolor Die Dentrudo, where blacks are painted white, where a black child with a painted face, blows water through a tube on to the others. Blacks actually took over the public space so as not to be attacked by white locals. This strengthened their community, using the ceremonies of the Congo and Cucumbis, that were celebrated in this the period.

In this context societies were formed called the Alumni Recreation Samba Schools. These associations are specific to the less affluent urban strata of Rio de Janeiro. They date from the late 1920 s, a time when street carnival activities were organized almost exclusively by the bourgeois of the city. Made up of mostly groups of blacks and mulattos, they were virtually unable to meet and dance in the streets and avenues of the city, even their own neighborhoods. They could just stand on the pavements of the streets as spectators. Over time, however, the talent of those excluded from the party, who ended up taking over the squares and plazas during the period of Momo, was recognized by the bourgeoisie and appreciated for the originality of their music, their instruments and the unusual strength and power of their dancing.

Absorbed by the bourgeois class in Rio, the samba rhythm came to be called Grand Carnival. That would be the sound broadcast worldwide as originating in Brazil, with its roots strongly in Rio de Janeiro. The first was the Samba School Mangueira, founded on April 28, 1928. Organized as Recreational Samba Schools, each group presents a parade on the main avenue consisting of the Front, followed by the Alas, floats, highlights, samba dancers, drums and the old guard (the older samba participants). All schools have a group of bahianas, which is composed of older women.

Today, there is a diversity of attractions that make up the street Carnival in Rio. On Maua Pier, several concerts are hosted of Brazilian pop music, as Rappa, J Quest and Monoblock, which can be watched by those less accustomed to samba. In addition, electronic music concerts take place during the period in various locations along the coast and in nightclubs. Some shows, like that of the Monoblock attracted about 400 thousand people to the beach. In addition, the dances, typical of Rio's Carnival of the twentieth century are somewhat changed, with a diverse audience and massive presence of tourists from Brazil and abroad.

When it comes to Rio, the international tourist mass, making its first trip to the country, usually settles in the circuit of central beaches, Copacabana, 
Ipanema or Leblon. These places have accommodation for all types of travelers, from international hostels, bed and breakfasts and simple hotels, up to luxury hotels like the Hotel Copacabana Palace.

The diversity of nationalities corroborates the picture of Rio de Janeiro as an international. Interesting details - such as family groups, or groups of friends or travelers who come to Brazil for the first time, are common in Rio. Other interesting observations will be analyzed further.

The questions put to foreign tourists were the same as in Ouro Preto and Recife and the Sense Units are described and analyzed below:

\section{1 - Brazil Tropical}

2 - First time in Brazil

3 - Beauty of Rio de Janeiro and the Brazilian

4 - Caipirinha and drinks at affordable prices

\section{5 - Size of the Carnival}

The image of sun and beach is ever present in the traveler. The tourist can experience what he saw in the agency brochures. Traveling with the family, first trip to Brazil is the image strongly promoted by tourist agency advertisements. The image represented by Brazil's Copacabana has transcended time, has become part of the image of the young, who see in Copacabana a synthesis of the country - sun, beach, sports and beautiful people. The foreign tourist mostly thinks that Brazil has only sunshine. When rain occurs, a normal event in February and March, there is general disappointment among foreigners. One of the peculiarities of Rio de Janeiro is that it has always been the port of entry to Brazil, mainly for south of the country, and its natural beauty has become one of the main attractions of Brazilian tourism.

The impact on the tourist who arrives in Rio de Janeiro is mostly positive, which is a function of the great beauty of the nature Rio. The grandeur of the Carnival stands out as an attraction for foreign tourists, who can have contact with the Rio Carnival Sambadrome. Carnival freedom, combined with the beauty of the Brazilian, sharpen the vision of the tourist who sees the differences between the carnival traditions of Brazil and his country.

Every country has a brand when it comes to drink. The caipirinha became the Brazilian beverage to the world. Especially in Rio, the caipirinha became a differentiating factor in the context both of culinary moments and relaxation, or as a part of the samba schools. The tourist enjoys a feijoada, which is always accompanied by the unfailing caipirinha.

A good part of foreigners coming to Brazil for Carnival go to Sambódromo, as audience or as participants in Block parades already catering to tourists in general, Brazilians or foreigners. However, the vast majority of foreigners, about $80 \%$ of them, do not participate in the Carnival Sambadromo, this means the Carnival of the blocks, the associations and the balls are now increasingly important in the Rio Carnival. There is an inherent need in the event to have the streets as busy as possible. 


\section{The image of Brazil and the influence of the Carnival}

Brazilian Carnival tourism in this context undoubtedly corresponds to the view of the foreign tourist when looking for information about the country. It is clear that it influences the imaginary world. Brazil has its Carnival and has walked the trend of globalization. This tendency is natural. The Brazilian Carnival is intrinsically linked to Brazil's image as a people and country. Moreover, there is an international recognition of the development experienced by the country in recent years. The very international crisis that occurred in 2008 helped to promote the view that Brazil is a confident emerging country, which has a large internal market and is part of the group of countries that are in a more comfortable situation with regard to international instability. This image of a democratic country, concerned for social integration of its population has also contributed to improving the perception of Brazil in the world.

We can say that the first hypothesis proved true in the interviews. The Carnival is acknowledged as a positive and important factor in the decision to travel to Brazil. The event attracts tourists who make a positive evaluation of the festival, and is an important factor in the reason why a tourist returns.

The second hypothesis was also proved in the research. In Rio de Janeiro most tourists interviewed, $70 \%$ were first-time travelers to Brazil. However, in Recife, the proportion is reversed; about $70 \%$ of respondents were visiting the country for the second time or more.

The vision of a tourist before coming to Brazil is divided into two groups: the tourists who came for the first time and the tourists who had been before. Within the second group, some had been several times. In most cases, the image of Brazil is linked to tropicalism. Sometimes it is connected to sport or the environment. However, what stands out is that the vast majority of first-time tourists to the country went in Rio de Janeiro.

In Ouro Preto, there is a division between first-time visitors and "second trip" tourists. In Recife, on the other hand, the majority of tourists have been in Brazil before. This demonstrates that the gateway to Brazil is Rio de Janeiro. This peculiar feature of being coastal brings commercial benefits to the city.

The second option, comprising the North and Northeast regions, is interesting in relation to the possibility of sustainable growth, both in terms of development of the reception, and in the adjustment of demand, there is room for growth in the future. The rate of growth manpower in these places can easily be enhanced by investments in training and staff development. The image of the foreign visitor about Brazil has changed little over recent decades. The images of Carnival and Football are trademarks that are still iconified in Brazil, even although they are beginning to lose ground to other issues such as the environment, social and economic. The growth of industry and of Brazilian products on the shelves of the world, a process started in the late twentieth century and early this decade, has been increasingly enhanced by efforts from both government and the private sector.

Several problems can be detected in the tourism sector in Brazil, mainly in the centers of the Northeast. The exploitation of manpower and service providers of the tourist industry is also a problem to be faced, as the instability of the seasonal 
tourism industry also brings problems of work relations and the concomitant effects on labor rights. Sexual tourism occurs before our eyes, with little or no resistance from the public sector. The image of sex tourism involving Northeastern cities such as Fortaleza, Natal and Recife especially should be the focus of attention of public administration.

The Northeast can use their comparative advantage, especially in relation to the sun, affordable prices and interaction with the unique culture of the Northeast, as a major asset in its international promotion. The future of tourism is the search for locations with originality, with the concept of integrated sustainable comfort without harming the environment, less carbon footprint, with environmental awareness and cultural integration.

On the question of culture, we emphasize that more than just fountains of wisdom, like cultural heritage in need of steady flows, the culture of the Carnival and its ephemerality are closer to the image of the zone, the flower that influences everything, but without knowing exactly the lure, the verve. What is known is that it just happens. There are many places where things happen and the Brazilian Carnival is just so: countless spirits fraternizing at times ephemeral. In our view, what happens to the Carnival and the stay of foreign tourists in Brazil, would be what the philosopher, writer and British diplomat Samuel Taylor Coleridge [6] called Suspension of Disbelief, referring to the will of the reader or viewer to accept as true the premises of a work of fiction, even though they are fantastic, impossible or contradictory. Is the suspension of the judgment in exchange for the assumption of entertainment.

Within this cultural context, the Carnival is the festival that brings together the differences across the Brazilian territory, mainly because it is celebrated by all sections of the population. The origins and history of people, the drumming of blacks, costumes and paintings on feathers of the Indians and the need to "be outside" caused by the tropical temperatures are stronger than politics, religion and the rules of society itself. The Carnival festival is a manifestation of the traditions people with one objective: revelry i.e. to have a good time, and this happens by different ways through the country. How we could notice by the interviews, this is the context found on the Carnival of Brazil, to the watchful eyes of foreigners.

\section{References}

[1] Bahl, Miguel. Legacy Ethnic and Tourist Offer, Torres: Brazil, p.p.19, 2004.

[2] Sardi, J. A., An analytical perspective of the educational context of UFOP: education, subjectivity and exacerbation of the pleasures, Havana: Cuba, 2001

[3] Featherstone, M., Dismiss the Culture: Globalization, postmodernism and identity. Sesc, São Paulo: Brazil, p.p. 43, 1997.

[4] Cascudo, L. C., Anthology of Brazilian Folklore, Global: Sao Paulo, 2002.

[5] Cascudo, L. C., Geography of Brazilian Myths, Sao Paulo: Brazil ,2002

[6] Coleridge, S.T., Literary Biography, 1817. 